\title{
The effect of disinfectants on fungi in pure culture and on different surface materials
}

\author{
HILKKA KOPONEN, HANNA AVIKAINEN and RISTO TAHVONEN
}

\begin{abstract}
Koponen, H., Avikainen, H. \& Tahvonen, R. 1992. The effect of disinfectants on fungi in pure culture and on different surface materials. Agric. Sci. Finl. 1: 587-596 (Dept. Pl. Biology, P. O. Box 28, SF-00014 University of Helsinki, Finland; Agric. Res. Centre of Finland, Inst. PI. Protect., SF-31600, Jokioinen, Finland)
\end{abstract}

The effect of eight disinfectants was tested on 11 fungi. The concentrations recommended by the manufacturers were mostly used in the present trials. Five and $15 \mathrm{~min}$ treatment times were too short for most preparations. The best efficacy was achieved at 60 min treatment time. In pure cultures, all disinfectants tested were most effective against Pythium sp. Overall, the most effective preparation was Desinfektol EL which was effective against all fungi tested at $5 \mathrm{~min}$ treatment time.

Wood surfaces were more difficult to disinfest than metal and plastic surfaces. Rhizoctonia solani and Verticillium dahliae were highly susceptible only to Desinfektol $\mathrm{EL}$, and $\mathrm{NaOCl}$ controlled Pythium sp. and Botrytis cinerea. None of the preparations controlled completely the other test fungi.

On metal surfaces the most effective disinfectants were Desinfektol EL and $\mathrm{NaOCl}$; moderately effective were Iobac P and Menno-Ter-forte. Korsolin was the least effective preparation. Verticillium dahliae and Phomopsis sclerotioides were difficult to kill. The easiest fungi to disinfest were Pythium sp., Rhizoctonia solani, B. cinerea, Fusarium avenaceum, F. culmorum, F. oxysporum, Mycocentrospora acerina and Phoma foveata.

Fungi grown on plastic surfaces were best controlled with Desinfektol EL. Also $\mathrm{NaOCl}, \mathrm{Menno}-\mathrm{Ter}$-forte and Iobac $\mathrm{P}$ were effective. Korsolin was the least effective preparation. The easiest fungi to eradicate were Pythium $\mathrm{sp}$. and $R$. solani. The most difficult fungi were $V$. dahliae and $P$. sclerotioides. Both peat and clay deteriorated the efficacy of the disinfectants except for Desinfektol EL.

Key words: disinfection, metal surface, plant pathogens, plastic surface, wood surface

\section{Introduction}

Farmers and agricultural advisors have been inquiring about the applicability of disinfectants for disinfection of greenhouses and storages. There are several commercial disinfectants on the market. Many of the preparations available are intended for use in hospitals, food industry and domestic animal farms, less frequently for disinfection of greenhouses and storages.

There is little experimental data in the literature on the effect of disinfectants on plant pathogenic fungi and their use for control of plant pathogens (BRIELMAIER 1985, BÅNG 1987, BöHMER 1983, 
LøSCHENKOHL et al. 1990, SUNDHEIM 1989).

In greenhouses it is not necessary to disinfect the soil, because the growth substrate is changed after each growing period and plastic containers are used. However, it is still important to disinfect the benches and equipment, because many plant pathogens may survive for long periods of time in structures and plant debris, even in soil, until the next growing season. Important plant diseases of cucumber and tomato seedlings in greenhouse include Pythium spp. and Rhizoctonia solani; diseases occuring later in the roots and stems of older plants include Phomopsis sclerotioides, Didymella bryoniae, Verticillium dahliae, Fusarium spp., Botrytis cinerea and Sclerotinia sclerotiorum (FLETCHER 1984). These pathogens may also be carried over from one place to another by means of the equipment and pots.

Pathogens in winter storages of potatos and vegetables are carried in with the products. Annual disinfection before the storage period reduces the number of pathogens persisting in the storage structures. Significant pathogenic fungi in storages of potatoes and vegetables include e.g. Fusarium spp., Botrytis cinerea, Mycocentrospora acerina, Phoma

Table 1. The disinfectants tested for control of fungi.

\begin{tabular}{|c|c|c|}
\hline Disinfectant & $\begin{array}{c}\text { Active ingredient } \\
\%\end{array}$ & $\begin{array}{c}\text { Tested } \\
\text { concentration } \\
\%\end{array}$ \\
\hline Desinfektol EL & Ethanol, 60.0 & undiluted \\
\hline Iobac P & Iodine, 1.8 & 3.0 \\
\hline Ipasept & $\begin{array}{l}\text { Quaternary ammonium } \\
\text { compounds, } 2.8\end{array}$ & 2.0 \\
\hline Korsolin & Glutaraldehyde, 10.0 & 1.0 \\
\hline Menno-Ter-forte & $\begin{array}{l}\text { Quaternary ammonium } \\
\text { compounds, } 32.5\end{array}$ & 1.0 \\
\hline $\begin{array}{l}\text { Sodium hypochlo- } \\
\text { rite }(\mathrm{NaOCl})\end{array}$ & Active chlorine, 10.0 & 10.0 \\
\hline Taloset & $\begin{array}{l}\text { Quaternary ammonium } \\
\text { compounds, } 3.5\end{array}$ & 2.0 \\
\hline Virkon S & $\begin{array}{l}\text { Potassium } \\
\text { peroxysulphate, } 60.0\end{array}$ & 1.0 \\
\hline
\end{tabular}

foveata, Sclerotinia sclerotiorum, Sclerotium cepivorum and Typhula sp. (SEPPÄNEN 1983, TAHVONEN $1981 \mathrm{a}, \mathrm{b}$ ).

The present study was undertaken in vitro to determine the effect of some commonly used disinfectants on plant pathogenic fungi in pure culture and on wood, plastic and metal surfaces, as well as the effect of peat and clay on the efficacy of disinfection. Some of the commonly used disinfectants, e.g. formaldehyde, are hazardous to the user's health. Therefore we tried to find alternatives. The effect of disinfectants on germination of fungal sclerotia was also tested as surviving structures of fungi are more resistant than the mycelium and the conidia. An effective disinfectant to control plant pathogenic fungi in greenhouses and winter storages of potatoes and vegetables was sought.

\section{Material and methods}

\section{Disinfectants}

A total of eight compounds (Table 1) were evaluated for their effectiveness in killing fungi in vitro. The concentrations used in the trials were those recommended by the manufacturers. Any deviations from these concentrations are specified in the tables. The disinfectants were diluted in water.

\section{Test fungi}

Eleven fungi, Botrytis cinerea, Didymella bryoniae, Fusarium avenaceum (only in cloth and wood surface tests), $F$. culmorum, $F$. oxysporum, Mycocentrospora acerina, Phoma foveata, Phomopsis sclerotioides, Pythium sp., Rhizoctonia solani and Verticillium dahliae from the collection of the Department of Plant Biology, Section of Plant Pathology (HPP), University of Helsinki, were tested against disinfectants in the vegetative phase. The age of inoculum was about three-four weeks. So the 
mycelia and the spores were well developed, but there were no resting bodies except chlamydospores or microsclerotia in F. oxysporum, M. aceri$n a, P$. sclerotioides and $V$. dahliae. The effect of the disinfectants on the germination of sclerotia was also tested on B. cinerea, $R$. solani, Sclerotium cepivorum, Sclerotinia sclerotiorum and Typhula $\mathrm{sp}$. The names of the fungi are mainly according to DOMSCH et al. (1980).

\section{Cloth test}

In the cloth test the fungi were grown on synthetic (nylon voile) gauze pieces (size approx. $1 \times 1 \mathrm{~cm}$ ) on PDA plates at room temperature in normal daylight. When visible fungal mycelium was spread from the inoculum plug to the cloth pieces on PDA surface, they were immersed in the test solutions for 5, 15, 30 and $60 \mathrm{~min}$. After treatment the upper side of the fungi growing test material was placed upwards on PDA, each on a separate plate. The treatments were replicated five times with four plate per replicate. Sterile water was used as a control treatment. The plates were tabulated when the culture in the control treatment covered the entire plate. The results were evaluated on a rating scale of $0-2$ : $0=$ no growth, $1=$ growth inhibited, $2=$ growth like in the control treatment. The figures were converted to efficiency percentages.

\section{Sclerotial test}

With the exception of Typhula sp. which was grown at $+5^{\circ} \mathrm{C}$, the fungi were grown at room temperature on PDA plates to produce sclerotia. The sclerotia of Rhizoctonia solani were grown on cabbage pieces. The sclerotia ( $20 \mathrm{pcs})$ in a gauze bag were immersed in the disinfection solutions for 60 min. After treatment each sclerotium was placed on a plate of its own for evaluation of viability of the sclerotia. The results were evaluated when the control culture covered the entire plate.

\section{Surface material}

The tested surface materials were untreated pine, stainless steel and polyethene plastic discs. They were approx. $3 \mathrm{~mm}$ in thickness and approx. $1 \mathrm{~cm}$ in diameter. The discs were sterilized by autoclaving (wood and metal) or with $90 \%$ ethanol (plastic). The test fungi were grown on these surfaces as described above in the cloth test and immersed in the test solution for 30 and $60 \mathrm{~min}$. The results were evaluated as + (fungal growth) or as - (no fungal growth). The figures in the tables are efficiency percentages.

The effect of organic material (peat and clay) on the disinfection efficiency was evaluated on polyethene plastic and steel surfaces. Plastic and steel discs approx. $1 \mathrm{~cm}$ in diameter and approx. $3 \mathrm{~mm}$ in thickness were used. The discs were contaminated with sterilized peat ( $15 \mathrm{~g}$ peat $/ 5 \mathrm{dl}$ water) and clay ( $80 \mathrm{~g}$ clay soil/8 $\mathrm{dl}$ water) suspension which was allowed to dry on the surface of the discs. The tests were carried out as described above in the surface material test except that the exposure time was 60 $\min$.

\section{Results}

In the cloth test the most effective disinfectant was Desinfektol EL which completely inhibited the growth of all test fungi. Moderately effective disinfectants were also Iobac P, Menno-Ter-forte and $\mathrm{NaOCl}$, although the growth inhibiting effect was not consistent in all fungi. Ipasept, Korsolin, Taloset and Virkon S (1\%) were weak disinfectants (Table 2).

In the cloth test the disinfectants were very effective against Pythium sp. and moderately effective against mycelia of Rhizoctonia solani. Most fungi were, however, difficult to eradicate. These include e.g. Verticillium dahliae and Mycocentrospora acerina. A treatment time of 5 or 15 min was too short. The most effective treatment time was $60 \mathrm{~min}$ (Table 2). 
Table 2. The effect of disinfectants on fungi growing on cloth pieces. Disinfectants: $1=$ Desinfektol EL, $2=$ Iobac P, $3=$ Ipasept, 4 = Korsolin, 5 = Menno-Ter-forte, $6=\mathrm{NaOCl}, 7=$ Taloset, $8=$ Virkon $\mathrm{S}$.

\begin{tabular}{|c|c|c|c|c|c|c|c|c|}
\hline \multirow[t]{2}{*}{ Fungus } & \multicolumn{8}{|c|}{ Disinfectant } \\
\hline & 1 & 2 & 3 & 4 & 5 & 6 & 7 & 8 \\
\hline & \multicolumn{8}{|c|}{ Minimum time min/efficiency $\%$} \\
\hline Botrytis cinerea & $5 / 100$ & $60 / 100$ & $60 / 78$ & $60 / 0$ & $60 / 90$ & $60 / 60$ & $60 / 55$ & $60 / 58$ \\
\hline Didymella bryoniae & $5 / 100$ & $60 / 100$ & $60 / 53$ & $60 / 30$ & $60 / 98$ & $30 / 100$ & $60 / 35$ & $60 / 95$ \\
\hline Fusarium avenaceum & $5 / 100$ & $60 / 100$ & $60 / 55$ & $60 / 38$ & $60 / 75$ & $60 / 98$ & $60 / 60$ & $60 / 63$ \\
\hline Fusarium culmorum & $5 / 100$ & $60 / 100$ & $60 / 13$ & $60 / 0$ & $60 / 65$ & $15 / 100$ & $60 / 60$ & $60 / 73$ \\
\hline Fusarium oxysporum & $5 / 100$ & $15 / 100$ & $60 / 18$ & $60 / 0$ & $60 / 70$ & $5 / 100$ & $60 / 65$ & $60 / 20$ \\
\hline Mycocentrospora acerina & $5 / 100$ & $60 / 25$ & $60 / 0$ & $60 / 2$ & $60 / 88$ & $15 / 100$ & $60 / 50$ & $60 / 73$ \\
\hline Phoma foveata & $5 / 100$ & $60 / 73$ & $60 / 45$ & $60 / 5$ & $60 / 93$ & $60 / 93$ & $60 / 38$ & $60 / 55$ \\
\hline Phomopsis sclerotioides & $5 / 100$ & $60 / 80$ & $60 / 68$ & $60 / 65$ & $60 / 98$ & $60 / 98$ & $60 / 63$ & $30 / 100$ \\
\hline Pythium sp. & $5 / 100$ & $5 / 100$ & $15 / 100$ & $15 / 100$ & $5 / 100$ & $5 / 100$ & $5 / 100$ & $5 / 100$ \\
\hline Rhizoctonia solani & $5 / 100$ & $30 / 100$ & $15 / 100$ & $60 / 25$ & $5 / 100$ & $60 / 100$ & $60 / 100$ & $60 / 63$ \\
\hline Verticillium dahliae & $5 / 100$ & $60 / 3$ & $60 / 0$ & $60 / 0$ & $60 / 18$ & $60 / 58$ & $60 / 50$ & $60 / 3$ \\
\hline
\end{tabular}

Table 3. The effect of disinfectants on the germination of sclerotia after $60 \mathrm{~min}$ treatment.

\begin{tabular}{|c|c|c|c|c|c|c|}
\hline Disinfectant & $\begin{array}{l}\text { Concen- } \\
\text { tration \% }\end{array}$ & $\begin{array}{l}\text { Botrytis } \\
\text { cinerea }\end{array}$ & $\begin{array}{c}\text { Rhizoctonia } \\
\text { solani }\end{array}$ & $\begin{array}{l}\text { Sclerotinia } \\
\text { sclerotiorum }\end{array}$ & $\begin{array}{l}\text { Sclerotium } \\
\text { cepivorum }\end{array}$ & Typhula sp. \\
\hline & \multicolumn{6}{|c|}{ Efficiency \% } \\
\hline Desinfektol EL & Undiluted & 100 & - & 100 & - & - \\
\hline \multirow[t]{2}{*}{ Iobac P } & 3.0 & 5 & 8 & 5 & 50 & 10 \\
\hline & 4.0 & 0 & - & 0 & 45 & 50 \\
\hline \multirow[t]{2}{*}{ Ipasept } & 2.0 & 0 & 17 & 0 & 10 & 5 \\
\hline & 3.0 & 0 & - & 0 & 35 & 0 \\
\hline \multirow[t]{2}{*}{ Korsolin } & 1.0 & 0 & 8 & 0 & 0 & 5 \\
\hline & 2.0 & 20 & - & 0 & 20 & 95 \\
\hline \multirow[t]{2}{*}{ Menno-Ter-forte } & 1.0 & 15 & 75 & 0 & 75 & 100 \\
\hline & 2.0 & 30 & - & 0 & 90 & 100 \\
\hline \multirow[t]{3}{*}{$\mathrm{NaOCl}$} & 1.0 & 100 & 0 & 15 & 0 & 100 \\
\hline & 2.0 & - & - & 8 & 0 & - \\
\hline & 3.0 & - & - & 8 & 10 & - \\
\hline \multirow[t]{2}{*}{ Taloset } & 1.0 & 0 & - & 0 & - & - \\
\hline & 3.0 & 80 & - & 0 & - & - \\
\hline \multirow[t]{2}{*}{ Virkon S } & 1.0 & 0 & - & 0 & 0 & 0 \\
\hline & 2.0 & 20 & 17 & 0 & 0 & 100 \\
\hline
\end{tabular}

In the sclerotial test Desinfektol EL inhibited the germination of Botrytis cinerea and S. sclerotiorum sclerotia. Menno-Ter-forte, $\mathrm{NaOCl}$ and Virkon S (2\%) inhibited the germination of Typhula sclerotia. However, none of the disinfectants provided complete control over the sclerotia of Sclerotium cepivorum and $R$. solani (Table 3 ).

Wood surfaces were difficult to disinfest. Only Desinfektol EL inhibited completely the growth of $V$. dahliae and $R$. solani, $\mathrm{NaOCl}$ the growth of 
Table 4. The effect of disinfectants on fungi growing on wood discs after 60 min treatment. Disinfectants: $1=$ Desinfektol EL, 2 = Iobac P, 3 = Ipasept, 4 = Korsolin, 5 = Menno-Ter-forte, $6=\mathrm{NaOCl}, 7=$ Taloset $3 \%, 8=$ Virkon S.

\begin{tabular}{|c|c|c|c|c|c|c|c|c|}
\hline \multirow[t]{2}{*}{ Fungus } & \multicolumn{8}{|c|}{ Disinfectant } \\
\hline & 1 & 2 & 3 & 4 & 5 & 6 & 7 & 8 \\
\hline & \multicolumn{8}{|c|}{ Efficiency \% } \\
\hline Botrytis cinerea & 0 & 0 & 0 & 0 & 0 & 100 & 0 & 0 \\
\hline Didymella bryoniae & 0 & 60 & 0 & 0 & 0 & 0 & 0 & 0 \\
\hline Fusarium avenaceum & 0 & 0 & 0 & 0 & 0 & 0 & 0 & 0 \\
\hline Fusarium culmorum & 0 & 0 & 0 & 0 & 0 & 0 & 0 & 0 \\
\hline Fusarium oxysporum & 0 & 0 & 0 & 0 & 0 & 0 & 0 & 0 \\
\hline Mycocentrospora acerina & 0 & 0 & 0 & 0 & 0 & 0 & 0 & 0 \\
\hline Phoma foveata & 0 & 0 & 0 & 0 & 0 & 0 & 0 & 0 \\
\hline Phomopsis sclerotioides & 0 & 0 & 0 & 0 & 0 & 0 & 0 & 0 \\
\hline Pythium sp. & 60 & 60 & 0 & 0 & 0 & 100 & 0 & 0 \\
\hline Rhizoctonia solani & 100 & 0 & 0 & 0 & 0 & 0 & 0 & 20 \\
\hline Verticillium dahliae & 100 & 0 & 0 & 0 & 0 & 0 & 0 & 0 \\
\hline
\end{tabular}

Pythium sp. and B. cinerea. The other disinfectants were ineffective against the test fungi (Table 4).

The metal surface was effectively disinfested from fungi with Desinfektol $\mathrm{EL}$ and $\mathrm{NaOCl}$. Menno-Ter-forte and Iobac $\mathrm{P}$ were effective against all test fungi except $V$. dahliae and Phomopsis sclerotioides (Table 5).

Organic material (peat and clay) did not reduce the efficacy of Desinfektol EL and $\mathrm{NaOCl}$ on metal surfaces. Iobac P and Menno-Ter-forte were also moderately effective on surfaces contaminated with peat. Peat did not reduce the efficacy of the disinfectants against Pythium sp, $R$. solani, Fusarium oxysporum, $F$. culmorum and Phoma foveata (Table 5).

Clay reduced most the efficacy of Ipasept, Korsolin, Menno-Ter-forte and Taloset on metal surfaces. $V$. dahliae and $B$. cinerea were difficult to eradicate. Inversely, metal surfaces contaminated with clay were easy to disinfest from Pythium sp. and rather easy from D. bryoniae, F. culmorum and $R$. solani (Table 5). Metal surfaces contaminated with clay were more difficult to disinfest than metal surfaces contaminated with peat.

The plastic discs were effectively disinfested from fungi with Desinfektol $\mathrm{EL}$ and $\mathrm{NaOCl}$; slightly less effective disinfectants were Iobac P and Menno-Ter-forte. Pythium sp., Mycocentrospora acerina and $R$. solani were highly susceptible to disinfectants (Table 6).

The plastic discs contaminated with peat were most effectively disinfested with Desinfektol EL and Menno-Ter-forte; effective disinfectants were also Iobac $\mathrm{P}$ and $\mathrm{NaOCl}$. Weak disinfectants were Ipasept, Taloset and Korsolin (Table 6). Pythium sp. and $P$. foveata were easy to eradicate, whereas $V$. dahliae, $P$. sclerotioides and $F$. oxysporum were not susceptible to disinfectants (Table 6).

Plastic pieces contaminated with clay were most effectively disinfested with Desinfektol EL. Most fungi were susceptible also to Iobac P, Menno-Terforte and $\mathrm{NaOCl}$ (Table 6). Easily eradicated fungi were Pythium sp., P. foveata, D. bryoniae, B. cinerea and $R$. solani, whereas $F$. oxysporum, $P$. sclerotioides and $V$. dahliae were difficult to eradicate (Table 6).

\section{Discussion}

In the laboratory tests of BÖHMER (1983), MennoTer-forte $(0.5 \%)$ has been shown to inhibit the growth of Fusarium oxysporum conidia at $5 \mathrm{~min}$ treatment, but $\mathrm{NaOCl}(1 \%)$ did not inhibit the growth of the fungus. In the present laboratory tests, $70 \%$ control was achieved over $F$. oxysporum 
Table 5. The effect of disinfectants and organic material on fungi on metal surfaces. Treatment time $60 \mathrm{~min}$. Disinfectants: 1 = Desinfektol EL, 2 = Iobac P, 3 = Ipasept, 4 = Korsolin, $5=$ Menno-Ter-forte, $6=\mathrm{NaOCl}, 7=\mathrm{Taloset} 3 \%, 8=\mathrm{Virkon} \mathrm{S}$.

\begin{tabular}{|c|c|c|c|c|c|c|c|c|c|}
\hline Fungus & $\begin{array}{l}\text { Organic } \\
\text { material }\end{array}$ & \multicolumn{7}{|c|}{ Disinfectant } & 8 \\
\hline & \multicolumn{9}{|c|}{ Efficiency \% } \\
\hline \multirow[t]{3}{*}{ Botrytis cinerea } & Clean $(\mathrm{N})$ & 100 & 100 & 100 & 40 & 100 & 100 & 100 & 100 \\
\hline & Peat $(\mathrm{P})$ & 100 & 100 & 100 & 40 & 100 & 100 & 0 & 100 \\
\hline & Clay (C) & 100 & 80 & 0 & 0 & 0 & 80 & 0 & 0 \\
\hline \multirow[t]{3}{*}{ Didymella bryoniae } & $\mathrm{N}$ & 100 & 100 & 100 & 0 & 100 & 100 & 100 & 60 \\
\hline & $P$ & 100 & 100 & 100 & 0 & 100 & 100 & 40 & 60 \\
\hline & $\mathrm{C}$ & 100 & 100 & 0 & 40 & 40 & 100 & 100 & 100 \\
\hline \multirow[t]{3}{*}{ Fusarium culmorum } & $\mathrm{N}$ & 100 & 100 & 100 & 100 & 100 & 100 & 100 & 60 \\
\hline & $\mathrm{P}$ & 100 & 100 & 100 & 100 & 100 & 100 & 100 & 60 \\
\hline & $\mathrm{C}$ & 100 & 100 & 0 & 0 & 0 & 100 & 0 & 100 \\
\hline \multirow[t]{3}{*}{ Fusarium oxysporum } & $\mathrm{N}$ & 100 & 100 & 100 & 100 & 100 & 100 & 100 & 0 \\
\hline & $\mathrm{P}$ & 100 & 100 & 100 & 100 & 100 & 100 & 60 & 0 \\
\hline & $\mathrm{C}$ & 100 & 100 & 0 & 0 & 40 & 100 & 20 & 60 \\
\hline \multirow[t]{3}{*}{ Mycocentrospora acerina } & $\mathrm{N}$ & 100 & 100 & 100 & 40 & 100 & 100 & 100 & 100 \\
\hline & $P$ & 100 & 100 & 100 & 40 & 100 & 100 & 0 & 100 \\
\hline & $\mathrm{C}$ & 100 & 80 & 20 & 0 & 20 & 100 & 40 & 80 \\
\hline \multirow[t]{3}{*}{ Phoma foveata } & $\mathrm{N}$ & 100 & 100 & 100 & 100 & 100 & 100 & 60 & 100 \\
\hline & $\mathrm{P}$ & 100 & 100 & 100 & 100 & 100 & 100 & 0 & 100 \\
\hline & $\mathrm{C}$ & 100 & 80 & 40 & 0 & 60 & 100 & 20 & 100 \\
\hline \multirow[t]{3}{*}{ Phomopsis sclerotioides } & $\mathrm{N}$ & 100 & 0 & 0 & 0 & 40 & 100 & 100 & 0 \\
\hline & $\mathrm{P}$ & 100 & 0 & 0 & 0 & 40 & 100 & 60 & 0 \\
\hline & $\mathrm{C}$ & 100 & 20 & 0 & 80 & 0 & 100 & 0 & 100 \\
\hline \multirow[t]{3}{*}{ Pythium sp. } & $\mathrm{N}$ & 100 & 100 & 100 & 100 & 100 & 100 & 100 & 100 \\
\hline & $\mathrm{P}$ & 100 & 100 & 100 & 100 & 100 & 100 & 100 & 100 \\
\hline & $\mathrm{C}$ & 100 & 100 & 40 & 100 & 60 & 100 & 100 & 100 \\
\hline \multirow[t]{3}{*}{ Rhizoctonia solani } & $\mathrm{N}$ & 100 & 100 & 100 & 80 & 100 & 100 & 100 & 100 \\
\hline & $\mathrm{P}$ & 100 & 100 & 100 & 80 & 100 & 100 & 100 & 100 \\
\hline & $\mathrm{C}$ & 100 & 80 & 40 & 40 & 60 & 100 & 100 & 100 \\
\hline \multirow[t]{3}{*}{ Verticillium dahliae } & $\mathrm{N}$ & 100 & 0 & 0 & 0 & 40 & 100 & 0 & 20 \\
\hline & $\mathrm{P}$ & 100 & 0 & 0 & 0 & 40 & 100 & 0 & 20 \\
\hline & C & 100 & 20 & 0 & 0 & 0 & 100 & 0 & 0 \\
\hline
\end{tabular}

with Menno-Ter-forte at $60 \mathrm{~min}$ treatment time in the cloth test, and $\mathrm{NaOCl}(1 \%)$ controlled completely $F$. oxysporum after 5 min treatment in the cloth test.

The recommended concentrations of the disinfectant (e.g. Menno-Ter-forte) were shown to control the conidia of $F$. avenaceum, $F$. culmorum, $F$. oxysporum and Verticillium dahliae after $10 \mathrm{~min}$ treatment (BRIELMAIER 1985). In the present laboratory tests, Menno-Ter-forte did not kill F. avena- ceum and $V$. dahliae after $60 \mathrm{~min}$ treatment. This is probably due to the fact the fungal cultures used in the trials contained in addition to conidia fungal mycelia and chlamydospores which are more resistant to disinfectants than the conidia.

In the laboratory trials of BAANDRUP (1983), Korsolin (2\%) and Menno-Ter-forte (1\%) inhibited the growth of $F$. oxysporum and Pythium debaryanum at 30 min treatment time. In the present trials, Pythium sp. was susceptible both to Korsolin (1\%) 
Table 6. The effect of disinfectants and organic material on fungi on plastic surfaces. Treatment time $60 \mathrm{~min}$. Disinfectants: 1 = Desinfektol EL, 2 = Iobac P, 3 = Ipasept, $4=$ Korsolin, $5=$ Menno-Ter-forte, $6=\mathrm{NaOCl}, 7=$ Taloset $3 \%, 8=$ Virkon S

\begin{tabular}{|c|c|c|c|c|c|c|c|c|c|}
\hline \multirow[t]{2}{*}{ Fungus } & \multirow{2}{*}{$\begin{array}{l}\text { Organic } \\
\text { material }\end{array}$} & \multicolumn{8}{|c|}{ Disinfectant } \\
\hline & & 1 & 2 & 3 & 4 & 5 & 6 & 7 & 8 \\
\hline & \multicolumn{9}{|c|}{ Efficiency \% } \\
\hline \multirow[t]{3}{*}{ Botrytis cinerea } & Clean $(\mathrm{N})$ & 100 & 60 & 0 & 0 & 80 & 100 & 0 & 100 \\
\hline & Peat $(\mathrm{P})$ & 100 & 100 & 60 & 0 & 100 & 100 & 0 & 20 \\
\hline & Clay (C) & 100 & 100 & 100 & 60 & 100 & 100 & 0 & 60 \\
\hline \multirow[t]{3}{*}{ Didymella bryoniae } & $\mathrm{N}$ & 100 & 100 & 80 & 0 & 100 & 100 & 80 & 80 \\
\hline & $P$ & 100 & 0 & 0 & 0 & 100 & 100 & 20 & 0 \\
\hline & $\mathrm{C}$ & 100 & 100 & 80 & 100 & 100 & 100 & 100 & 100 \\
\hline \multirow[t]{3}{*}{ Fusarium culmorum } & $\mathrm{N}$ & 100 & 100 & 20 & 100 & 0 & 80 & 60 & 20 \\
\hline & $\mathrm{P}$ & 100 & 100 & 0 & 20 & 100 & 100 & 0 & 80 \\
\hline & C & 100 & 100 & 0 & 0 & 20 & 100 & 20 & 0 \\
\hline \multirow[t]{3}{*}{ Fusarium oxysporum } & $\mathrm{N}$ & 100 & 100 & 0 & 0 & 100 & 100 & 0 & 20 \\
\hline & $P$ & 100 & 100 & 0 & 0 & 40 & 20 & 0 & 0 \\
\hline & C & 100 & 60 & 0 & 0 & 0 & 0 & 0 & 0 \\
\hline \multirow[t]{3}{*}{ Mycocentrospora acerina } & $\mathrm{N}$ & 100 & 100 & 100 & 100 & 60 & 100 & 100 & 80 \\
\hline & $P$ & 100 & 80 & 0 & 0 & 100 & 100 & 80 & 40 \\
\hline & C & 100 & 40 & 20 & 0 & 100 & 100 & 0 & 40 \\
\hline \multirow[t]{3}{*}{ Phoma foveata } & $\mathrm{N}$ & 100 & 80 & 100 & 0 & 100 & 100 & 100 & 80 \\
\hline & P & 100 & 100 & 80 & 20 & 100 & 80 & 20 & 100 \\
\hline & C & 100 & 100 & 100 & 100 & 100 & 100 & 0 & 100 \\
\hline \multirow[t]{3}{*}{ Phomopsis sclerotioides } & $\mathrm{N}$ & 100 & 0 & 0 & 0 & 100 & 100 & 100 & 0 \\
\hline & P & 100 & 0 & 0 & 0 & 20 & 80 & 0 & 0 \\
\hline & C & 100 & 0 & 0 & 0 & 0 & 60 & 60 & 0 \\
\hline \multirow[t]{3}{*}{ Pythium sp. } & $\mathrm{N}$ & 100 & 100 & 100 & 100 & 100 & 100 & 100 & 100 \\
\hline & P & 100 & 100 & 100 & 100 & 100 & 100 & 40 & 100 \\
\hline & C & 100 & 100 & 80 & 100 & 100 & 100 & 40 & 100 \\
\hline \multirow[t]{3}{*}{ Rhizoctonia solani } & $\mathrm{N}$ & 100 & 20 & 100 & 100 & 100 & 100 & 100 & 100 \\
\hline & $\mathrm{P}$ & 100 & 60 & 60 & 60 & 100 & 40 & 40 & 80 \\
\hline & C & 100 & 100 & 80 & 100 & 100 & 100 & 60 & 80 \\
\hline \multirow[t]{3}{*}{ Verticillium dahliae } & $\mathrm{N}$ & 100 & 0 & 20 & 0 & 80 & 100 & 0 & 0 \\
\hline & $P$ & 100 & 0 & 0 & 0 & 20 & 60 & 60 & 0 \\
\hline & $\mathrm{C}$ & 100 & 0 & 40 & 0 & 80 & 40 & 0 & 0 \\
\hline
\end{tabular}

and Menno-Ter-forte (1\%) after 15 min treatment. The most effective disinfectants were Desinfektol $\mathrm{EL}$ and $\mathrm{NaOCl}$. Desinfektol EL controlled all tested fungi. Effective disinfectants were also Iobac $\mathrm{P}$ and Menno-Ter-forte, whereas Ipasept, Korsolin and Taloset were weak disinfectants.

In the present tests, the disinfectants were most effective against Pythium sp. In Oomycetes the chemical composition of the cell wall is different from that of Deuteromycetes or Ascomycetes, which is probably the reason for the differences in efficacy between the fungal species. Also in other studies Oomycetes have been shown more susceptible to disinfectants than Deuteromycetes (BAANDRUP 1983). In an agar test carried out in Sweden, Korsolin (1\%) and Menno-Ter-forte $(0.5 \%)$ did not inhibit the growth of Botrytis cinerea, Didymella bryoniae and Phomopsis sclerotioides at 1 min treatment time (JOHANSSON 1985). In the present study, $60 \mathrm{~min}$ treatment time was too 
short for Korsolin to kill the fungi, whereas for Menno-Ter-forte (1\%) $60 \mathrm{~min}$ exposure time was quite sufficient to kill $D$. bryoniae and $P$. sclerotioides. The results show that Menno-Ter-forte requires at least $60 \mathrm{~min}$ exposure time and the concentration of compound should not to be lower than $1 \%$.

In the present study, the sclerotia of the fungi proved very resistant to disinfectants. None of the disinfectants provided complete control over the sclerotia of Sclerotium cepivorum, Sclerotinia sclerotiorum and Rhizoctonia solani. Only Desinfektol EL inhibited the germination of sclerotia of B. cinerea and $S$. sclerotiorum and $\mathrm{NaOCl}$ that of B. cinerea and Typhula sp. at 60 min treatment time. A treatment time of $60 \mathrm{~min}$ with Menno-Ter-forte (2\%) did not prevent the growth of S. sclerotiorum although, according to BÖHMER (1985), soaking of sclerotia for $2 \mathrm{~h}$ in Menno-Ter-forte (1\%) inhibited their growth. It is probably more important to use an exposure time of at least $2 \mathrm{~h}$ for sclerotial control than higher concentration. During the longer exposure time the disinfectant will penetrate deeper in the tissues of sclerotia than during a short exposure time. Desinfektol EL may be recommended to control sclerotia of $B$. cinerea and $S$. sclerotiorum, and $\mathrm{NaOCl}$ to control B. cinerea and Typhula sp. at one hour exposure time.

Fungi growing on wood surface were difficult to disinfest. Only Desinfektol EL controlled completely $V$. dahliae and $R$. solani, and $\mathrm{NaOCl} P y t-$ hium sp. and B. cinerea. Other disinfectants did not give complete control over the test fungi. Studies carried out in Sweden have shown that Iobac P (3 and 5\%) and Menno-Ter-forte (1 and 5\%) do not disinfest wood pieces infected with Phoma and Fusarium (BÅNG 1987). Also in this study Iobac $P$ and Menno-Ter-forte were ineffective against $P$. foveata, $F$. avenaceum, $F$. culmorum and $F$. oxy sporum growing on wood surface.
In the present study, Korsolin proved to be a weak disinfectant. It did not kill fungi growing on wood surface. Also in other studies (SUNDHEIM 1989) Korsolin has been shown ineffective against fungi growing on wood surfaces.

In studies carried out in Norway, Menno-terforte $(5 \%)$ has been effective on wood surface against $B$. cinerea, but ineffective against $P$. sclerotioides and D. bryoniae (SUNDHEIM 1989). In the present study, the recommended concentration (1 $\%$ ) of Menno-Ter-forte was ineffective on wood surface against all test fungi. How long the fungus has grown on the wood surface will affect besides disinfectant concentration the efficacy of disinfection as the mycelium of fungi will partly grow in tree tissues, causing differences in test results.

The present study showed that organic material reduces the efficacy of most disinfectants. It is therefore important to clean thoroughly the surfaces before disinfection. In the laboratory tests, Desinfektol EL proved to be the most effective disinfectant on wood, steel and plastic surfaces contaminated with peat and clay. Not even organic material reduced the efficiency of the preparation. In the present study, the test fungi cultures were under one month old, and the viability of the conidia and the mycelia was very high. In practice the situation is very different, the fungal spores, mycelia and resting bodies in cold storages and greenhouses are not freshly grown, and the viability of pathogens has probably decreased. Thus, disinfectants with a wide effect on fungi e.g. $\mathrm{NaOCl}$, Iobac $\mathrm{P}$ and Menno-Ter-forte can be used on steel and plastic surfaces although the efficacy is not perfect. For disinfection of wood surfaces, only $\mathrm{NaOCl}$ and Desinfektol EL, which were effective against some test fungi may be recommend. Also other limitations, such as safety and corrosivenes, may affect the choice of disinfectant to be used. 


\section{References}

BAANDRUP, M. 1983. Desinfektionsmidler. Specialrapport vid Köpenhamns universitet. (Ref. Johansson 1985).

BẢNG, U. 1987. Försök med desinfektionsmedel. Spor potatisodl. 5 (2): 32-34.

Bо̆нмеR, B. 1983. Untersuchungen zum Einsatz von Desinfektionsmitteln im Zierpflanzenbau. Gesunde Pfl. 35; 189-197.

—. 1985. Nicht alle Mittel wirken unter Schmutzbelastung. Gärtnerbör. Gartenw. 85: 836-838.

BRIELMAIER, U. 1985. Wirkung von Desinfektionsmitteln auf pilzliche Krankheitserreger, die im Zierpflanzenbau von Bedeutung sind. Meded. Fac. Landbouww. Rijksuniv. Gent 50/3b: 1235-1242.

Domsch, K. H., Gams, W. \& Anderson, T.-H. 1980. Compendium of soil fungi. Academic Press. London. Vol. 1. $859 \mathrm{p}$.

Fletcher, J. T. 1984. Diseases of greenhouse plants. 351 p. Longman, London.

Johansson, A.-K. 1985. Löpande desinfektion i växthus av Xanthomonas pelargonii och X. begoniae. Disinfektion in greenhouses of Xanthomonas pelargonii and X. begoniae. Institutionen för växt- och skogsskydd. (Sveriges Lantbr. Univ.) Examensarbeten 1985 (5) Uppsala. 67 p. Loschenkohl, B., Dinesen, I. G. \& Thinggaard, K. 1990.
Afprøving af desinfektionsmidler. Gartn. Tid. 106: 1324-1325.

SEPPÄNEN, E. 1983. Fusariums of potato in Finland VIII. Occurrence of the pathogens causing potato dry rot and gangrene. Ann. Agric. Fenn. 22:115-119

Sundheim. L. 1989. Desinfeksjonsmiddel mot soppar. Akt. Stat. Fagtj. Landbr. 3: 89-95.

TAHVONEN, R. 1981 a. Storage fungi of onion and their control. J. Scient.Agric. Soc. Finl. 53:27-41.

- 1981 b. Storage fungi of cabbage and their control. J. Scient.Agric. Soc. Finl. 53:211-227.

\section{Manuscript received June 1992}

Hilkka Koponen

Department of Plant Biology

P. O. Box 28

SF-00014 University of Helsinki, Finland

Hanna Avikainen

Risto Tahvonen

Agricultural Research Centre of Finland

Institute of Plant Protection

SF-31600 Jokioinen, Finland 


\title{
SELOSTUS
}

\section{Desinfiointiaineiden teho sieniin puhdasviljelmillä ja erilaisilla pintamateriaaleilla}

\author{
HilkKa Koponen, Hanna AVIKAINEN ja Risto TAHVONEN \\ Helsingin yliopisto ja Maatalouden tutkimuskeskus
}

Tutkimuksessa testattiin kahdeksan desinfiointiaineen tehoa 11 sieneen. Kokeissa käytettiin useimmiten valmistajan suosittelemaa käyttöväkevyyttä. Kokeet tehtiin laboratoriokokeina liottamalla sientä sisältäviä kangaspaloja 5,15 tai $60 \mathrm{mi}-$ nuuttia desinfiointiainelaimennoksessa. Desinfiointiaineiden tehoa tutkittiin myös puhtailla sekä savella tai turpeella liatuilla puu-, metalli- ja muovipinnoilla.

Tutkimuksissa todettiin, että viiden ja viidentoista minuutin vaikutusajat olivat useilla valmisteilla liian lyhyitä. Paras teho saatiin tunnin käsittelyllä. Kangaspalakokeissa kaikki tutkitut desinfiointiaineet tehosivat hyvin Pythium- sieneen. Valmisteista tehokkain oli Desinfektol EL. Myös $\mathrm{NaOCl}$, Iobac $\mathrm{P}$ ja Menno-Ter-forte toimivat varsin hyvin useimpiin sieniin. Heikkotehoisin oli Korsolin.

Desinfiointiaineet tehosivat puupinnoilla huonommin kuin metalli- ja muovipinnoilla. Puukiekoilla kasvaviin Rhizocto- nia solani- ja Verticillium dahliae- sieniin tehosi hyvin vain Desinfektol EL. NaOCl tehosi Botrytis cinerea- ja Pythium sp.-sieniin.

Metallipinnoilla tehokkaimpia valmisteita olivat Desinfektol EL ja $\mathrm{NaOCl}$ sekä melko tehokkaita Menno-Ter-forte ja Iobac P. Heikoin valmiste oli Korsolin. Vaikeita sieniä puhdistaa olivat $V$. dahliae ja Phomopsis sclerotioides. Helpoimpia sieniä hävittää olivat Pythium sp., R. solani, B. cinerea, Fusarium spp., Mycocentrospora acerina ja Phoma foveata.

Muovipinnalla kasvaviin sieniin paras valmiste oli Desinfektol EL. Myös NaOCl, Menno-Ter-forte ja Iobac P olivat hyviä. Heikoin valmiste oli Korsolin. Helpoimmin puhdistuivat Pythium sp. ja $R$. solani. Vaikeimpia sieniä olivat $V$. dahliae ja $P$. sclerotioides. Turve ja savi heikensivät useiden valmisteiden puhdistustehoa. Desinfektol EL:n ja $\mathrm{NaOCl}$ : tehoa lika ei vähentänyt. 